\title{
Persistence of microcystin production by Planktothrix agardhii (Cyanobacteria) exposed to different salinities
}

Julia Vergalli, Stéphanie Fayolle, Audrey Combes, Evelyne Franquet \& Katia Comte 


\title{
Persistence of microcystin production by Planktothrix agardhii (Cyanobacteria) exposed to different salinities
}

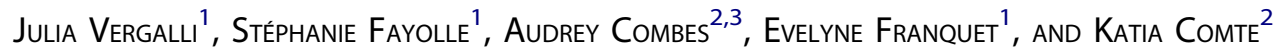 \\ ${ }^{1}$ Aix Marseille Univ., Univ. Avignon, CNRS, IRD, IMBE, Service 431, Marseille Cedex 20, France \\ ${ }^{2}$ UMR 7245 MCAM CNRS-MNHN, Muséum National d'Histoire Naturelle, 12 rue Buffon CP 39, Paris Cedex 05 F-75231, France \\ ${ }^{3}$ Dept of Analytical, Bioanalytical Sciences and Miniaturization (LSABM), CNRS, ESPCI Paris, PSL Research University, Paris Cedex 05,75 231, France
}

\begin{abstract}
Recent reports predict increases in harmful cyanobacteria in water systems worldwide due to climatic and environmental changes, which would compromise water quality and public health. Among abiotic changes, higher salinities are expected to promote the growth of certain harmful species, such as Planktothrix agardhii, which forms blooms in brackish waters. Since $P$. agardhii is a common producer of cyanotoxin, we investigated the growth and tolerance of this species when exposed in vitro to a range of salinities, while assessing variations in its microcystin diversity and production in batch cultures during a time-frame experiment spanning 18 days. The study revealed salt acclimation of the brackish $P$. agardhii, which continued to produce microcystins in salty cultures, while maintaining its growth capacity at low to medium $\mathrm{NaCl}$ (ranging from 0 to $7.5 \mathrm{~g} \mathrm{I}^{-1}$ ). With higher concentrations (10 to $15 \mathrm{~g} \mathrm{I}^{-1}$ ) significantly less growth occurred, corresponding to the shortening of cyanobacterial filaments, which nevertheless maintained their metabolic functions, as revealed by the high intensity of chlorophyll autofluorescence and persistent microcystin production. These findings showed that moderate to high salt levels do not inhibit microcystin production by $P$. agardhii, at least for several weeks. This raises questions concerning the persistence of harmful cyanobacteria in shallow water systems more exposed to evaporation and consequently to an increase in salinity in the future, as predicted by various climate models.
\end{abstract}

\section{INTRODUCTION}

The massive occurrence and proliferation of cyanobacteria worldwide are serious issues, as their bloom-forming ability impairs water quality (Twoney et al. 2002) in several ways, e.g. by increasing turbidity, reducing biodiversity, and eventual anoxia of the water column. In addition, some common species can produce various toxic metabolites, such as hepatotoxins and/or neurotoxins (Chorus \& Bartram 1999). The most frequently found toxic metabolites in waterbodies, including brackish areas (Sivonen \& Jones 1999), are hepatotoxic microcystins (MCs), which can affect all living organisms from ciliates to fish (Combes et al. 2013; Ressom et al. 1994) and threaten human health (Chorus \& Bartram 1999; Pouria et al. 1998).

MCs are cyclic heptapeptides that strongly (and irreversibly) inhibit serine-threonine protein phosphatases type 1 and 2A (Pearson et al. 2010), leading to cell disruption and even death (Djediat et al. 2011). MCs have many structural variations, depending on the L-amino acid at positions 2 and 4, respectively, from the overall MC architecture; to date, over 200 MC variants have been identified (Spoof \& Catherine 2017) with different cytotoxic potentials depending on the MC variant tested (Shimizu et al. 2014). While studies concerning biosynthesis and chemical processes involving MCs are ongoing, the forces underlying toxin production, i.e. the ecological and biological functions of MCs for the producing cells, remain elusive and mostly contradictory (Babica et al. 2006). Various hypotheses for the possible roles of MCs have been proposed, including allelopathic effects (Leao et al. 2009), grazer defences, and adaptation for light harvesting (Kaebernick \& Neilan 2001). Recent findings suggest involvement in intracellular processes and primary metabolism (Zilliges et al. 2011) while excluding an essential role for growth (Hesse \& Kohl 2001). Moreover, one of the most challenging questions is how the environment influences changes in MC concentration during cyanobacterial blooms. Indeed, a better understanding of environmental factors triggering and/or involving variations in MC production and changes in the composition of toxic vs non-toxic cells is very much required to help predict potential health hazards.

Numerous studies have shown that certain environmental parameters may influence MC production in toxic cells, including (1) the prevalence of toxic clones vs non-toxic ones (Briand et al. 2005) during unfavourable conditions (Kurmayer et al. 2004), (2) increases in the level of MCs in toxic cells (Sivonen \& Jones 1999), and (3) changes in MC variant composition (Pearson et al. 2010; Tonk et al. 2005). 
Among the possible causal factors are nutrient concentration (Downing et al. 2005), temperature and light (Wiedner et al. 2003), iron abundance (Sevilla et al. 2008), and pH (Song et al. 1998). Much less is known regarding many other abiotic parameters such as hydrologic variability, water bioavailability and salinity oscillations (N'Dong et al. 2014). Besides, the results are largely inconsistent, as many factors, both abiotic and biotic, may act in synergy and affect the physiological state of the cells at different levels (Davis et al. 2009).

Recent reports tend to predict that climatic change will exacerbate the dominance of harmful cyanobacteria in aquatic ecosystems worldwide (Carey et al. 2012; Paerl \& Paul 2012). Indeed, eutrophication exacerbated by human activity coupled with environmental changes, such as rising temperature and enhanced stratification of the water column, should trigger and increase the frequency, biomass, and duration of harmful cyanobacterial proliferation of specific species in waterbodies (Fastner et al. 1999; Hagemann 2011; Paerl \& Otten 2013). With regards to global warming, different climate models forecast warmer surface waters, which will contribute to an increase in salinity due to evaporation in shallow water systems (Pearl \& Huisman 2008). These ecosystems, including Mediterranean lakes and ponds, will be more impacted by stochastic episodes of gradual and repetitive increased salinity (due to higher periods of drought) rather than drastic salinity shocks (Nielsen et al. 2008). It is believed that oscillations in precipitation, including periods of intensive rainfall (i.e. floods) and increase in land runoff, might affect salinity levels of sensitive ecosystems such as estuarine areas, wetlands, lagoons and brackish areas (Cloern \& Jassby 2012; Teikaki et al. 2019). Such events could affect the distribution of bloom-forming species from freshwater to coastal areas (Lehman et al. 2005; Reguero et al. 2015) - especially if they are able to tolerate moderate to high salt levels (Paerl \& Otten 2013). Thus, rapid runoff, including toxic cyanobacterial transport, may contaminate and thus impair aquaculture, fisheries, and vegetation in downstream waters (Preece et al. 2017; Robson \& Hamilton 2003).

Planktothrix agardhii (Gomont) Anagnostidis \& Komàrek is one of the most common freshwater MC-producers in temperate areas (Chomerat et al. 2007) and has been reported to produce blooms in brackish waters (from 3 to $11 \mathrm{~g} \mathrm{l}^{-1}$ $\mathrm{NaCl}$; Rojo \& Alvarez Cobelas 1994; Villena \& Romo 2003). However, there are few data regarding the influence of salinity on MC production because these widespread MC-producing species are encountered mainly in freshwater. While $P$. agardhii can persist in brackish areas, it is important to investigate whether a rise in salinity affects MC production in P. agardhii, as meteorological models tend to predict increased salinisation in shallow Mediterranean areas due to climatic changes (Nielsen et al. 2008); however, experiments on salt stressors in vivo are lacking. Therefore, we investigated the response of a dominant cyanobacterial strain of $P$. agardhii originating from an oligohaline pond to a salinity gradient, aiming to determine (1) the influence of salinity of various concentrations on P. agardhii bloom development (growth and morphological changes) in batch cultures over a period of 18-20 days; and, (2) the influence of salinity on effective MC production by $P$. agardhii.

\section{MATERIAL AND METHODS}

\section{Strain isolation and culture conditions}

The strain of $P$. agardhii used in this study was collected from Olivier Pond, near Istres, just outside the city of Marseille (in the south of France; $43^{\circ} 30.46 \mathrm{~N}$ and $4^{\circ} 59.17 \mathrm{E}$ ). Olivier Pond is a eutrophic, oligohaline waterbody (average salinity $3 \mathrm{~g} \mathrm{l}^{-1}$ ), area of $c .225$ ha and maximum depth of $10 \mathrm{~m}$. P. agardhii is the dominant cyanobacterium throughout the year (Vergalli 2013). Water samples were collected at the pond surface during a $P$. agardhii bloom to isolate filaments. After isolating a single filament (Rippka 1988), five clones were purified and only one was microcystin positive. The MC-producing strain was maintained for several years under non-axenic conditions in Z8 liquid medium (Kotai 1972), at $22^{\circ} \mathrm{C}$, using a light:dark cycle of 14:10 h with constantly bubbling air to ensure homogeneity and to provide sufficient inorganic carbon. The 'Brack' strain was assigned to $P$. agardhii, according to morphological criteria as per Komárek \& Anagnostidis (2005) and maintained in the Paris Museum Collection (PMC-MNHN) under reference PMC1014.18.

\section{Experimental setup}

$\mathrm{NaCl}$ was added to $\mathrm{Z} 8$ medium to obtain salinities of 3, 5, 7.5, 10,12 , and $15 \mathrm{~g} \mathrm{l}^{-1}$ and transferred into 250-ml Erlenmeyer flasks. Five replicates of each salinity treatment were established and checked with a conductivity metre (WTW LF330, Weilheim, Germany). The control $(n=3)$ corresponded to a culture maintained in $\mathrm{Z} 8$ medium only $\left(\mathrm{NaCl}=0 \mathrm{~g} \mathrm{l}^{-1}\right)$. Each flask was then inoculated with P. agardhii PMC1014.18 pre-culture in exponential growth phase and adjusted to obtain an initial $\mathrm{OD}_{750}=0.1$ measured using a Shimadzu UV-1700 (Kyoto, Japan) spectrophotometer. Batch cultures were maintained in growth chambers under the same experimental conditions described above. Flasks were regularly replaced to homogenize the light exposure in the growth chambers.

\section{Growth measurements}

The growth kinetics of $P$. agardhii PMC1014.18 strain cultures were monitored by measuring optical density at $750 \mathrm{~nm}$. Growth rate $(\mu)$ was calculated as follows:

$$
\mu=\ln \mathrm{x} 2-\ln \mathrm{x} 1 / \mathrm{t} 2-\mathrm{t} 1
$$

where $t 1$ and $t 2$ are time [ $\mathrm{t}$ : start of the exponential phase; $\mathrm{t} 2$ (day): end of the experiment]; and $x 2$ and $x 1$ correspond to biomass (expressed in OD values) at time $\mathrm{t}$ (with $\mathrm{t} 2>\mathrm{t} 1$ ).

Biovolumes (BV) were assessed in $\mu \mathrm{m}^{3}$ based on the cylindrical shape of filaments, according to Sun \& Liu (2003):

$$
\mathrm{BV}=0.5 \Pi \mathrm{lw}
$$

where 1 is filament length $(\mu \mathrm{m})$ and $w$ is filament width $(\mu \mathrm{m})$. A mean of 20 filaments was randomly measured in a counting chamber, using a micro-scale with a Nikon Labphoto2 microscope (Tokyo, Japan).

Fluorescence microscopy was performed with a Zeiss Primo Star microscope equipped with an AxioCam IcC1 
camera. Epifluorescence images were recorded with specific filter (CY3) for chlorophyll $a$ and acquired with the same time exposure setting (AxioVision LE software).

\section{Characterisation of MC variants}

Three $\mathrm{ml}$ of culture $(\mathrm{OD}=0.6)$ of the PMC1014.18 strain was centrifuged at $4000 \times g$ for $10 \mathrm{~min}$ at $4{ }^{\circ} \mathrm{C}$. The supernatant was discarded, and the pellet was resuspended in $1 \mathrm{ml}$ of methanol:water $(90: 10, \mathrm{v}: \mathrm{v})$ followed by four pulses of sonication on ice for $30 \mathrm{sec}$. The mixture was centrifuged at $8000 \times g$ for 15 minutes at $4{ }^{\circ} \mathrm{C}$. Supernatant was collected, filtered (GF/C $1.2 \mu \mathrm{m}$ pore size $\times 2.1-\mathrm{mm}$ diameter), and evaporated using a speed-vac concentrator at $40{ }^{\circ} \mathrm{C}$. The extract was then resuspended with $100 \mu \mathrm{l}$ water with $0.1 \%$ formic acid and centrifuged at $4000 \times g$ for $5 \mathrm{~min}$ at $4{ }^{\circ} \mathrm{C}$. The supernatant was saved and transferred into a $200-\mu l$ conical insert and directly injected into a LC/ESI-MS (Liquid Chromatography/ Electrospray Ionisation-Mass Spectrometry) system.

LC/ESI-MS and LC/ESI-MS/MS experiments were performed on a liquid chromatograph (LC; UltiMate $3000^{\circ}$, Dionex, San Diego, California, USA) coupled to a quadrupoletime of flight (Q-TOF) hybrid mass spectrometer (Pulsar, Applied Biosystems-Foster City, USA) equipped with an electrospray ionization source (ESI). Chromatographic separation was conducted on an ACE3-C18 reverse-phase column $(100 \mathrm{~mm} \times$ $1 \mathrm{~mm} \times 3 \mu \mathrm{m})$. Mobile phases contained MilliQ water $0.1 \%(\mathrm{v} / \mathrm{v})$ + formic acid (A), and acetonitrile $0.07 \%+$ formic acid (v/v) (B). LC separation was achieved at a flow rate of $40 \mu \mathrm{min}^{-1}$ using a gradient elution from $10 \%$ to $30 \%$ of solvent $B$ in 5 min; then, from $30 \%$ to $70 \%$ B in $17 \mathrm{~min}$; held at 70\% B for $5 \mathrm{~min}$; returned from $70 \%$ to $10 \% \mathrm{~B}$ in $3 \mathrm{~min}$; and held at $10 \% \mathrm{~B}$ for $15 \mathrm{~min}$. The MS was operated with an ESI source in positive ion mode. For mass spectra, capillary voltage was set to $2500 \mathrm{~V}$ with a declustering potential of $20 \mathrm{~V}$. Full scan mass spectra were performed from 100 to $1500 \mathrm{~m} / \mathrm{z}$ for $1 \mathrm{sec}$ per scan in continuum mode. Fragmentation spectra were obtained in automatic mode using nitrogen as a collision gas, with collision energy automatically determined by the software according to mass-to-charge ratio $(\mathrm{m} / \mathrm{z})$ values.

MS/MS spectra were analysed manually for highlighted spectra which contained the fragment ion $(\mathrm{m} / \mathrm{z}=135.1)$ characteristic of MC fragmentation. All other ion fragments present on the fragmentation spectra were used to elucidate the structure of the MCs. LC/ESI-MS data were processed using BioAnalyst 1.1. Molecular weight distribution of species (ranging from $100 \mathrm{Da}$ to $1500 \mathrm{Da}$ ) observed in each sample was generated using the LC-MS reconstruct option. As the signals observed for both MC standards were close, the proportion of each variant was calculated by comparing the peak area corresponding to a given MC variant to the total peak area of all MC variants in a sample.

\section{MC concentration}

Microcystin concentration (MC) was determined by Enzyme Linked Immuno-Sorbent Assay (ELISA) using an MC-ADDA ELISA kit (Abraxis LLC-Warminster, Pennsylvania, USA). ELISA tests were applied to supernatants from the cultures previously disrupted by sonication on ice (2 pulses of $1 \mathrm{~min}$, maximum speed) according to a previous protocol (Combes et al. 2013). Mixture was then centrifuged at $8000 \times g$ for $15 \mathrm{~min}$ at $4{ }^{\circ} \mathrm{C}$. Supernatant was collected and cleaned, according to instructions specific to seawater samples ['Technical bulletin for microcystins in brackish and seawaters samples' (Abraxis)] to avoid certain matrix effects and potential salt interference. Measurements were performed in duplicate on different samples exposed to each salinity treatment on days $0,2,6,8,10$ and 18 . The limit of detection was $c .0 .26$ $\mathrm{ppb}\left(\mu \mathrm{g} \mathrm{l}^{-1}\right)$. MC content was expressed in $\mu \mathrm{g} \mathrm{l}^{-1}$ equivalent to MC-LR. Due to the positive correlation between biovolume (i.e. quantitative unit) and biomass (i.e. $\mathrm{OD}_{750}$ values; $\mathrm{r} 2=0.80 ; n=40$, Fig. S2), MC content was converted and normalised per biomass $\left(\mathrm{OD}_{750}\right)$ as a proxy of $\mathrm{MC}$ quota to compare different MC patterns over time by minimising the growth factor.

\section{Statistical analyses}

Growth curves were fitted with the best trend approximation from absorbance measurements over time, following the equation of Kahm et al. (2010):

$$
\mathrm{y}(\mathrm{t})=\mathrm{A} / 1+\exp (4 \mu / \mathrm{A}(\lambda-\mathrm{t})+2)
$$

where $\mathrm{A}$ is the asymptote of the curve, an estimation of maximal population density reached during the life cycle; $\mu$ is maximum slope of the growth curve and characterises exponential growth phase (days 6 to 18); $\lambda$ is lag phase period of growth (i.e. day 2).

Two parameters (growth rate and maximal density), obtained from the logistic curves generated with the 'grofit' package (Kahm et al. 2010), were used to compare growth under various salinities. Normality and homoscedasticity were systematically checked using the Shapiro-Wilk and the Fligner-Killeen tests, respectively. Consequently, significant differences in growth (growth rate, biomass and filament length) between salinities were identified by one-way analysis of variance (ANOVA; $n=5$ ) and Tukey's post-hoc test. Differences in MC concentrations were evaluated by KruskalWallis test (among salinity treatments) and by Mann-Whitney $U$ statistic when MC patterns were compared to the control. Pearson correlation coefficients were calculated between growth variables and MC concentrations. All statistical tests were carried out in the R-2.14.0 environment and Statview (Roth et al. 1995).

\section{RESULTS}

\section{Cell growth and morphological changes induced by various $\mathrm{NaCl}$ concentrations}

Optical density $\left(\mathrm{OD}_{750}\right)$ was recorded daily (from t0 to t18) to monitor culture growth and calculate growth rates ( $\mu$ max). While the highest salinity $\left(15 \mathrm{~g} \mathrm{l}^{-1}\right)$ had a drastic effect on growth (Fig. 1), the PMC1014.18 strain persisted and grew in low to high salinity (from 3 to $12 \mathrm{~g} \mathrm{l}^{-1}$ ) over the 18-day experiment. 


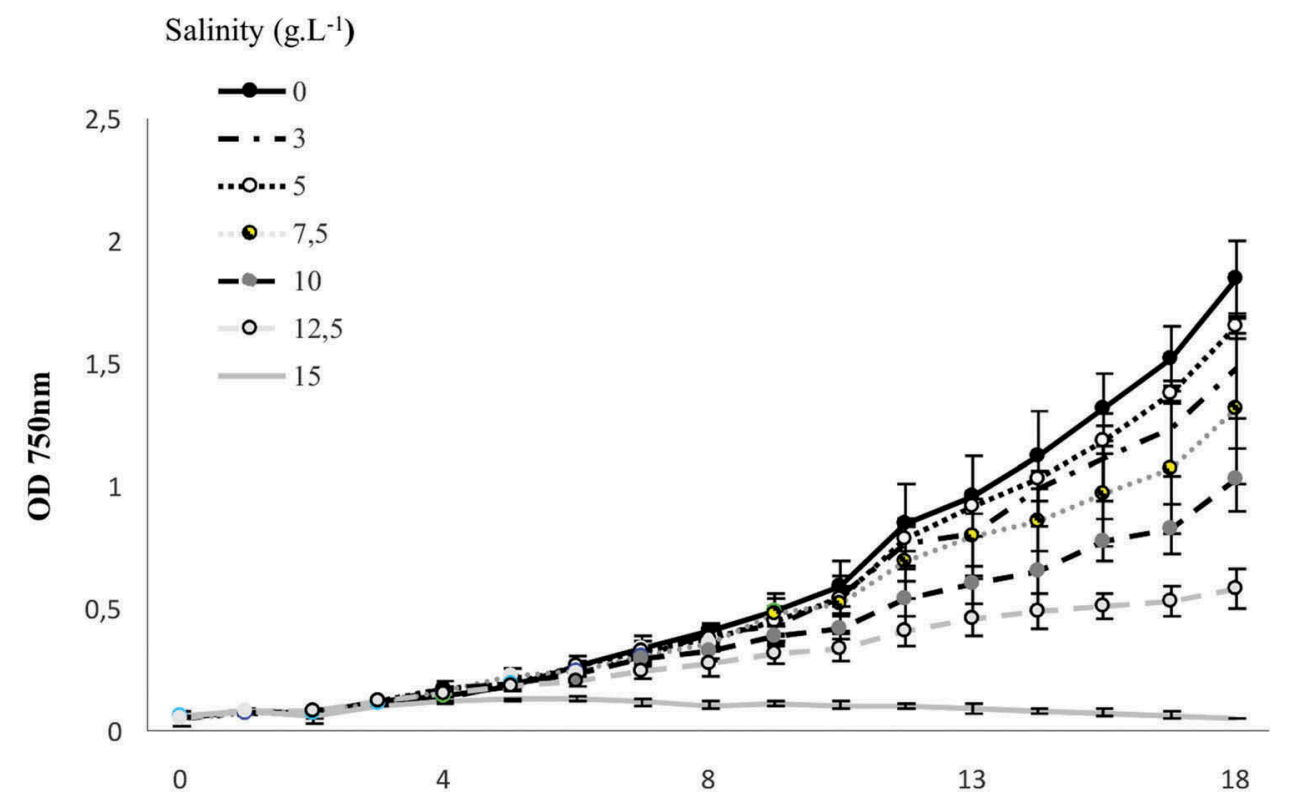

Time (day)

Fig 1. Growth dynamics of Planktothrix agardhii PMC1014.18 at different $\mathrm{NaCl}$ concentrations, obtained using OD750 values ( $n=5, \pm$ SD) from day 0 to day 18 (A) and fitted with the 'grofit' package.

Two growth profiles were distinguished: one included the control and the low salt concentrations and corresponded to a progressive increase in growth and a similar growth rate (ANOVA, $P>0.05$ ); and another that corresponded to the high salt concentrations $\left(7.5\right.$ to $12.5 \mathrm{~g} \mathrm{l}^{-1}$ ) that revealed a significant decrease in growth rate, and cell density (Table 1), especially at day 8 .

Additionally, microscopic observations, performed every two days to estimate filament size, detected morphological changes in whole cells and filament lengths (Fig. 2). The physiological state of filaments was assessed by light and epifluorescent microscopy, taking intact morphology and chlorophyll autofluorescence intensity as indicators of survival (Fig. 3-10, S3-10). The decrease in chlorophyll content with increasing salinity was correlated with total biovolumes, i.e. following morphological changes, and to a reduction in filament size (Fig. 2). While filaments were c. $240 \mu \mathrm{m}$ long at the beginning of the experiment $(\mathrm{t} 0)$, morphological variation was noted as early as days 2 to 8 for moderate treatments ( 5 to

Table 1. Descriptive parameters, including the growth rate and cell density, were determined from growth curves fitted by the "grofit" model. The different letters mentioned above $(a, b, c)$ indicate significant differences between the salinity treatments (Tukey's test, $P<0.01$ ).

\begin{tabular}{lcccccc}
\hline Salinity $\left(\mathrm{g} . \mathrm{L}^{-1}\right)$ & \multicolumn{2}{c}{ Growth rate $\mu\left(\mathrm{day}^{-1}\right)$} & \multicolumn{3}{c}{ Max. Density $\left(10^{3}\right.$ cell/ml $)$} \\
\hline 0 & 0,25 & $\pm 0,05$ & a & 2,4 & $\pm 0,1$ & a \\
3 & 0,19 & $\pm 0,02$ & a & 2,3 & $\pm 0,4$ & b \\
5 & 0,20 & $\pm 0,01$ & a & 2,6 & $\pm 0,2$ & a \\
7.5 & 0,15 & $\pm 0,02$ & ab & 2,3 & $\pm 0,5$ & b \\
10 & 0,12 & $\pm 0,02$ & ab & 2,2 & $\pm 0,6$ & bc \\
12.5 & 0,05 & $\pm 0,01$ & b & 0,9 & $\pm 0,6$ & c \\
15 & 0 & - & & 0,01 & - & \\
\hline
\end{tabular}

$7.5 \mathrm{~g} \mathrm{l}^{-1}$ ), with a significant increase in filament length up to a maximum $(521 \mu \mathrm{m}$ vs the control; ANOVA, $P<0.05)$. During these morphological changes, all filaments had bright chlorophyll $a$ fluorescence (Figs S5, S6) corresponding to the integrity of the cells and to photosynthetic pigments which led to the maintenance of primary metabolic functions after several days under moderate salinities.

Filament elongation was observed for cultures at 5 to $7.5 \mathrm{~g}$ $1^{-1} \mathrm{NaCl}$ between days 2 and 8 (ANOVA, $P<0.01$ ), followed by reductions in length beyond day 10 (not significantly different from the control; Figs 2, S3-10). For high salinities (12.5 to $\left.15 \mathrm{~g} \mathrm{l}^{-1} \mathrm{NaCl}\right)$ a significant reduction in filament length was detected after 14 days until the end of the experiment (day 20), with a mean length not exceeding $60 \mu \mathrm{m}$ (day 20) vs the usual $350 \mu \mathrm{m}$ for the control (Figs 2, 4, 5), 78). A remarkably high number of short fragments with only 5-10 cells were observed at $15 \mathrm{~g} \mathrm{l}^{-1} \mathrm{NaCl}$ by the end of the experiment (Figs 9, 10). Typical morphologies are shown in Figs 5, 8-10. Nevertheless, high intensity chlorophyll autofluorescence was still detected in short filaments even after 20 days of incubation (Figs 8,10 ), suggesting the continued viability of most cells within the broken filaments.

\section{Characterisation of MC profile in $P$. agardhii PMC1014.18}

Characterization of the MC variant composition (Figs S1-S3) was performed by LC coupled to ESI mass spectrometry (LC/ ESI-MS/MS) to identify the chemo-type profile of the strain grown under optimal conditions (i.e. the control), as MC diversity may exist within the same species (Shimizu et al. 2014; Tonk et al. 2005). Five MC variants (two major and 


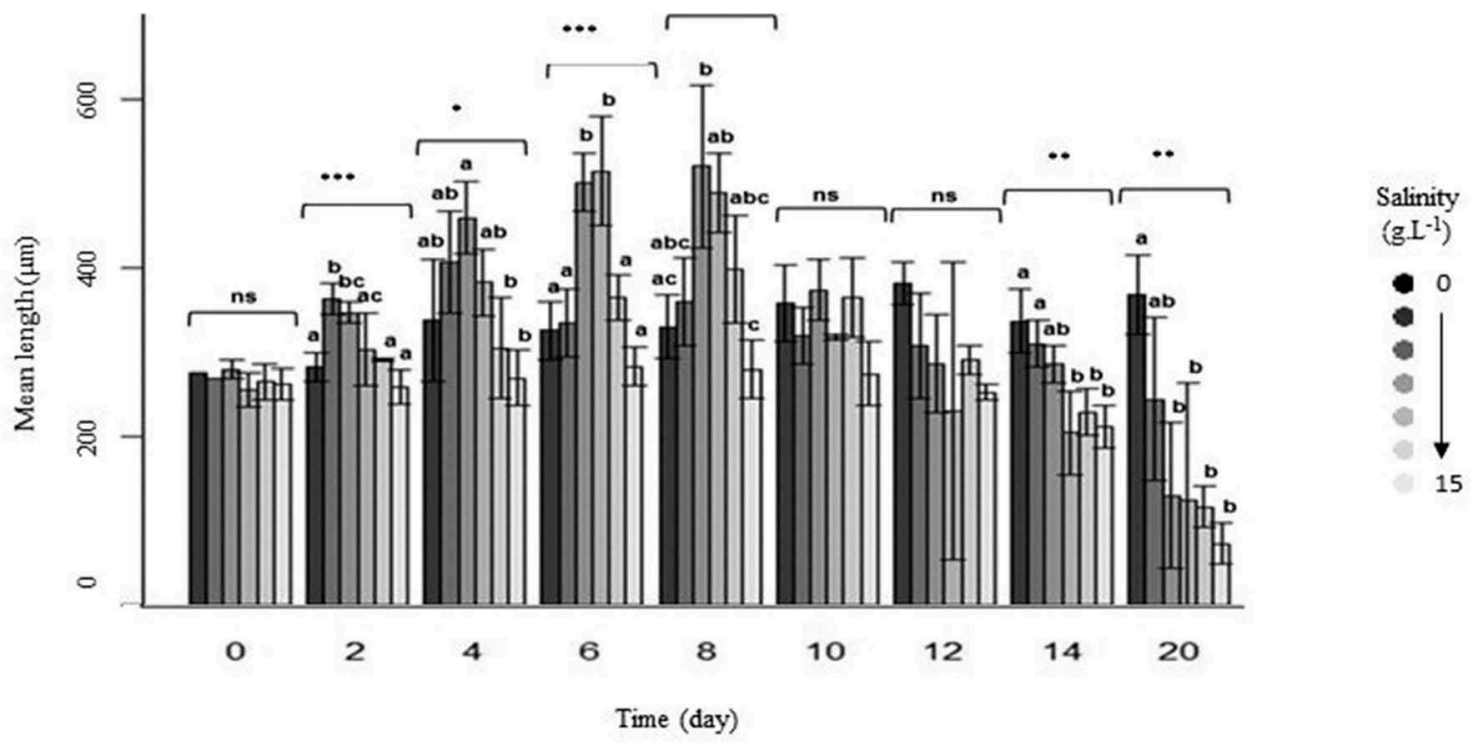

Fig 2. Variations in filament length of Planktothrix agardhii PMC1014.18 for cultures grown at different $\mathrm{NaCl}$ concentrations. Means $\pm s(\mathrm{n}=60)$ with different letters $(\mathrm{a}, \mathrm{b}, \mathrm{c})$ show significant differences between $\mathrm{NaCl}$ concentrations $(P<0.05$, ANOVA, Tukey's post-hoc test). Asterisks $(*)$ indicate differences from control (day $=0)$ sizes (NS $=$ not significant; ${ }^{*}=P<0.05 ;{ }^{* *}=P<0.01 ;{ }^{* * *}=P<0.001$ ).

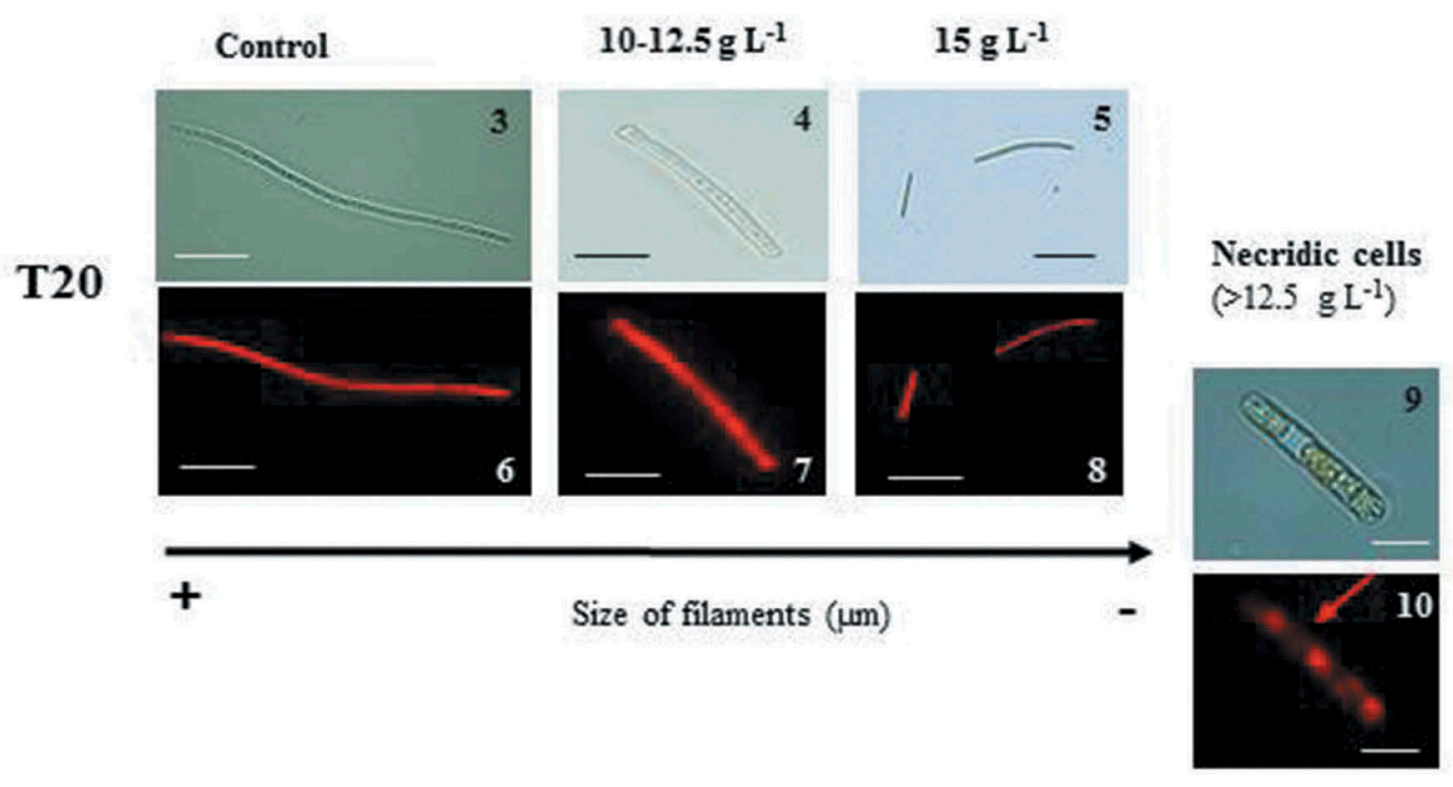

Figs 3-10 Bright field and epifluorescence microscopy of Planktothrix agardhii PMC1014.18 showing different sized filaments at day 20 (T20) based on chlorophyll autofluorescence (CY3 filter).

Figs 3-5. Bright field microscopy after 20 days.

Fig. 3. Filament size in control. Scale bar $=20 \mu \mathrm{m}$.

Fig. 4. Filament size at $10-12.5 \mathrm{~g} \mathrm{I}^{-1}$. Scale bar $=10 \mu \mathrm{m}$.

Fig. 5. Filament size at $15 \mathrm{~g} \mathrm{I}^{-1} \mathrm{NaCl}$. Scale bar $=30 \mu \mathrm{m}$.

Figs 6-8. The same filaments as in Figs 3-5 with epifluorescence microscopy.

Fig. 6. Filament size in control. Scale bar $=20 \mu \mathrm{m}$;

Fig. 7: Filament size at $10-12.5 \mathrm{~g} \mathrm{l}^{-1}$ Scale bar $=10 \mu \mathrm{m}$;

Fig. 8: Filament size at $15 \mathrm{~g} \mathrm{I}^{-1} \mathrm{NaCl}$. Scale bar $=30 \mu \mathrm{m}$.

Fig. 9. Short fragment with necridic cells observed in bright field at $>12.5 \mathrm{~g} \mathrm{I}^{-1}$. Scale bar $=10 \mu \mathrm{m}$.

Fig. 10. Short fragment with necridic cells observed with epifluorescence microscopy; red arrow indicates necridia (non-fluorescent cells). Scale bar $=10 \mu \mathrm{m}$.

three minor) were determined from the cultured PMC1014.18 strain (Table 2).

Based on Adda fragment signals (m/z 135.1), the MS/MS spectra, and the retention times of other ions (identical to MS standards and their MS/MS spectra), two major doubly- charged ions $[\mathrm{M}+2 \mathrm{H}]^{2+}$ (Table 2) were identified as [Asp3] MC-RR and [Asp3]MC-LR, respectively Together, these represent $93 \%$ of MCs present in this strain. Among the three minor ions, only one was clearly characterised as demethylated [Asp3]MC-HtyR (Table 2), while the doubly- 
Table 2. LC-ESI-MS determination of individual MC-variants detected in the 'Brack' strain. The identification of the MC-variant corresponds to ions detected on the mass spectra $(\mathrm{m} / \mathrm{z})$ and retention time (RT) compared to the standards. The proportions for each MC-variant are also included in the table. The $\mathrm{m} / \mathrm{z}=512.8 ; 491.3$ and 523.3 with the RT time of $16.8 ; 19.2$ and $18.7 \mathrm{~min}$ were identified and confirmed using the corresponding MC standard. *Variants obtained under optimal conditions. Microcystins were quantified using [Asp3] MC-RR and [Asp3] MC-LR standards.

\begin{tabular}{|c|c|c|c|c|c|}
\hline Peak & $\mathrm{m} / \mathrm{z}$ & $\mathrm{MH}^{+}$ & $\begin{array}{l}\text { rTmin - rTmax } \\
\text { (in min) }\end{array}$ & $\begin{array}{l}\text { Variants of } \\
\text { MCs }\end{array}$ & $\begin{array}{l}\text { Proportion (\%) of } \\
\text { MC variants* }\end{array}$ \\
\hline 1 & 512.8 & 1024.6 & $16.7-17.1$ & [Asp3]MC-RR & 83 \\
\hline 2 & 523.3 & 1045.6 & $18.6-18.9$ & [Asp3]MC-HtyR & 2 \\
\hline 3 & 491.3 & 981.6 & 18.9-19.4 & [Asp3]MC-LR & 10 \\
\hline 3 & 502.2 & 1003.4 & $19-19.4$ & $\begin{array}{l}\text { Undetermined } \\
\text { MC }\end{array}$ & 1 \\
\hline 4 & 516.2 & 1031.4 & $20.8-21.2$ & $\begin{array}{c}\text { DeMC-YR ou } \\
\text { [Asp3, Dha7] } \\
\text { MC-HtyR }\end{array}$ & 4 \\
\hline
\end{tabular}

charged $[\mathrm{M}+2 \mathrm{H}]^{2+}(\mathrm{m} / \mathrm{z}=516.2$ with a retention time $(\mathrm{RT})$ of $21 \mathrm{~min}$ ) was assigned to be one of either [Asp3]MC-YR or [Asp3, dha7] MC-HtyR. The ion $\mathrm{m} / \mathrm{z}=502.2$ was undetermined and could not be assigned to [Asp3]MC-LR, as referred to in Yuan et al. (1999).

\section{Impact of salinity treatments on MC concentration}

To simplify analysis, and to obtain a better idea of the MCs present in the cell cultures, quantification of total MCs, including both extra- and intracellular MC fractions, was performed using a microtiter plate MC-Adda ELISA for all salinity treatments. Total MC concentrations $\left(\mu \mathrm{g}^{-1}\right)$ were positively correlated with biomass (i.e. OD values) as suggested by the high $\mathrm{r}^{2}$ values for all salinity treatments except $15 \mathrm{~g} \mathrm{l}^{-1}\left(\mathrm{r}^{2}=0.037\right.$; Fig. 11). All salt conditions led to similar MC concentration profiles, including a progressive increase in $\mathrm{MC}$ content from days 0 to 12 , followed by a maximal concentration at day 18 for 0 to $12.5 \mathrm{~g} \mathrm{l}^{-1} \mathrm{NaCl}$ (Kruskal Wallis, $P>0.05$ ). At $15 \mathrm{gl}^{-1}$, a maximal peak was present at day 18, contrasting with a concomitant arrest in cell growth $(\mu=0)$.

Since a positive correlation was obtained between biovolumes $\left(\mu \mathrm{m}^{3}\right)$ and biomass (OD values, Fig. S4) for all samples $\left(\mathrm{r}^{2}=0.85, n=70\right)$, we were able to normalise MC content ( $\mu \mathrm{g}$ equivalent) per biomass as a proxy of MC quota to discriminate $\mathrm{MC}$ profiles at various salinities and over time so as to minimise the biomass factor. Here, four distinct MC concentration profiles were obtained, depending on the time frame and salinity concentrations involved (two-way ANOVA, $P<0.05)$. A first group was observed between 3 and $7.5 \mathrm{~g}$ $1^{-1}$ and the control (Kruskal-Wallis, $P>0.05$ ), where the MC quota peaked at day 2 followed by a progressive decline from day 8 to 18 . Some slight differences were detected for the $5 \mathrm{~g}$ $1^{-1}$ treatment (group 2) at days 6 and $8(P<0.05$; Fig. 12) for which a high $\mathrm{MC}$ value was still noted at day 2 , but without the constant decline of $\mathrm{MC}$ levels previously observed in group 1 and the control. For these groups, the MC quota was negatively correlated with the logarithm of biomass ( $\left.\mathrm{r}=-0.82, P=5.8^{\mathrm{e}-11}, n=42\right)$ and biovolumes $(\mathrm{r}=-0.76$, $P=5.2^{\mathrm{e}-09}, n=42$ ) throughout the experiment (days 2 to 18 ). A third MC profile was characterised for the 10 and $12.5 \mathrm{~g} \mathrm{l}^{-1}$ treatments, including a rather stable MC concentration throughout the experiment with a moderate increase at days 6 and 8 (Fig. 12) that differed significantly from the control $(P<0.01)$. The last group involved the highest salinity level $\left(15 \mathrm{~g} \mathrm{l}^{-1}\right)$ and exhibited an increase in MC concentration from day 2 to day 10 with a maximal value seven times higher than control $(P<0.001)$ at the end of the experiment (Fig. 12). As ELISA was applied to the whole culture (i.e. extracellular and intracellular fractions), it was not possible to confirm whether the MC concentrations arose from viable cells or from the media, suggesting a release of MCs after cell death.

\section{DISCUSSION}

\section{Effects of salinity on growth and morphology of P. agardhii PMC1014.18}

Our results highlight differences in growth phases of $P$. agardhii related to salt concentration, including a general decrease in growth rate as salinity increased (from $7.5 \mathrm{~g} \mathrm{l}^{-1}$ to $12 \mathrm{~g} \mathrm{l}^{-1}$, with growth heavily impaired at $15 \mathrm{~g} \mathrm{l}^{-1}$ salinity. However, the Planktothrix strain can maintain its growth under brackish water conditions (from 0 to $9 \mathrm{~g} \mathrm{l}^{-1}$; Chomerat et al. 2007), revealing a higher tolerance to salinity than previous studies (Orr et al. 2004; Chomerat et al. 2007; Komárek \& Anagnostidis 2005). Nevertheless, the low (observed at 10 to $12 \mathrm{~g} \mathrm{l}^{-1}$ ) to very low growth of the strain (at $15 \mathrm{~g} \mathrm{l}^{-1}$ ) coupled with morphological changes observed throughout the experiment, suggest that salt stress was still insufficient to produce drastic effects on population survival. While no significant differences were detected for the different salinities during the lag phase $(P>0.05$ from 0 to 2 days), a rapid increase in filament length occurred from days 4 to 8 for cultures exposed to 10 and $12.5 \mathrm{~g} \mathrm{l}^{-1}$ salinity (Figs 2, S56). Elongation could be the signal for cellular growth dysfunction or disruption in development (Singh \& Montgomery 2013a, 2013 b), which prevent proper cell division in the presence of this stressor. This temporary step was followed by a contrasting significant reduction in filament length after 12 days for 10 to $15 \mathrm{~g} \mathrm{l}^{-1}$ (Fig. 2), and the appearance of an increasing number of short filaments (one-sixth of controls) at the end of experiment (day 20) for higher salinities (up to $10 \mathrm{~g} \mathrm{l}^{-1}$, Fig. 2). Some studies demonstrated that salt stress inhibits cell division after several days at $0.5 \mathrm{M} \mathrm{NaCl}$ (Ferjani et al. 2003), which could explain the increasing frequency of small filaments observed here. Moreover, the presence of broken filaments suggests cell damage (Montgomery 2015), and has already been reported as a cyanobacterial stress response to environmental pressures (Poulickova et al. 2004; Singh \& Montgomery 2013a). Under these conditions, the shortened filaments could be a defence mechanism used by cells to preserve energy (Romo \& Miracle 1993) and maintain integrity of the few cells remaining. Indeed in vivo chlorophyll autofluorescence revealed a high intensity fluorescence signal in the short fragments at $15 \mathrm{~g} \mathrm{l}^{-1}$ (Figs 8-10), which, combined with light microscopy, indicated that cell integrity, as well as the active photosynthetic pigments within cells, were maintained (Figs 5-9). Although the best way to assess cell viability is the use of fluorescent dye-staining methods (Pouneva 1997), assessing pigment autofluorescence may be 


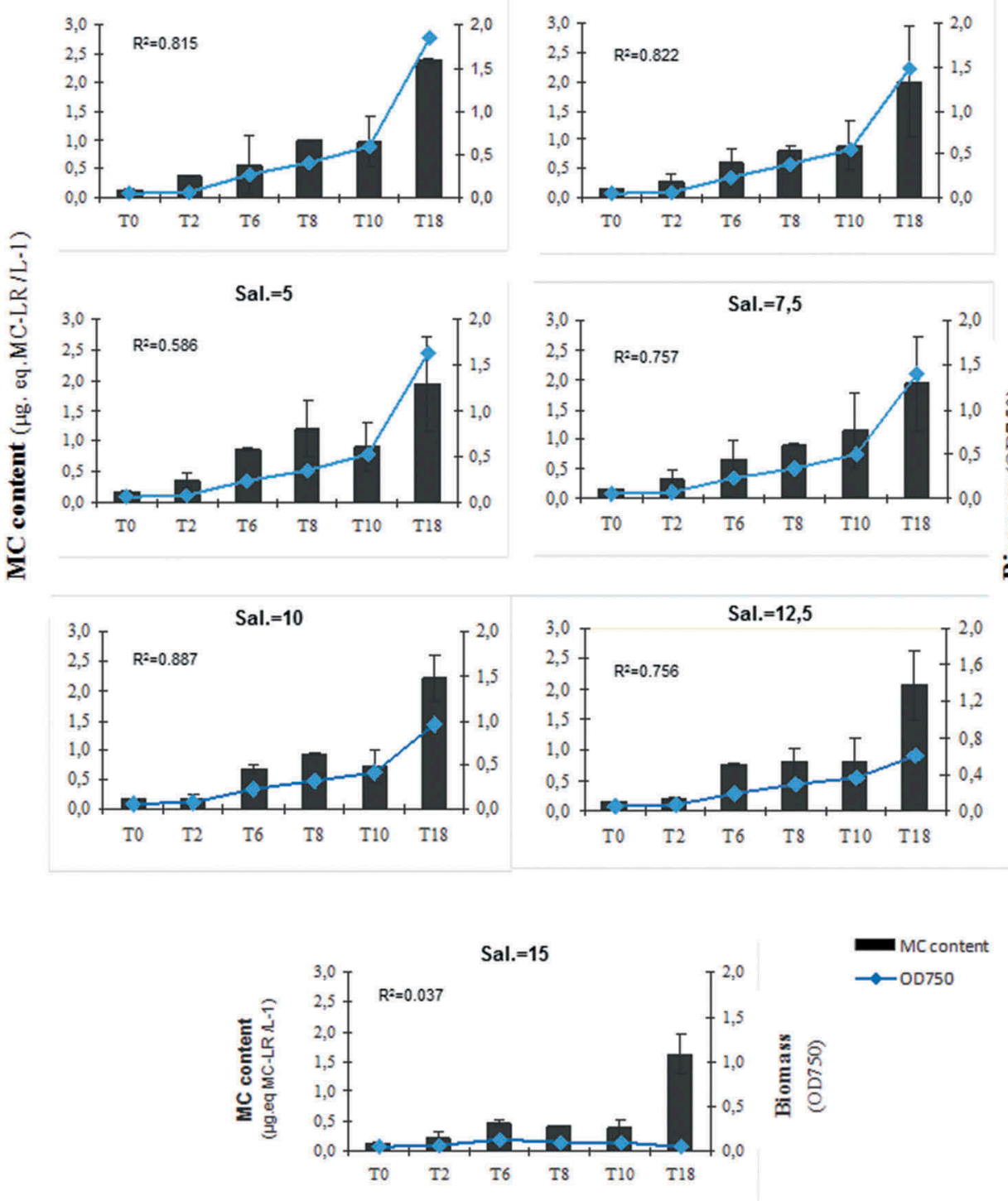

Fig. 11. Variation in MC content ( $\mu \mathrm{g}$ eq. MC-LR/ $\mathrm{I}^{-1}$ ) of Planktothrix agardhii PMC1014.18 (means $\left.\pm s, n=3\right)$ compared to biomass $\left(\mathrm{OD}_{750}\right.$ values) over time (18 days).

a convenient method to evaluate the physiological state of cells (Corrobé et al. 2017).

At 12.5 to $15 \mathrm{~g} \mathrm{l}^{-1}$ salinity, there was intense fluorescence in most short fragments, whereas a small number of cells exhibited non-photosynthetic fluorescent signals (dark cells; Figs 9, 10), which corresponded to necridia or 'suicidal-cells' (Figs 9, 10; Yuan et al. 1999), which split filaments in two (Castenholtz \& Waterbury 1989). Interestingly, these suicidal cells can be considered a dispersal strategy, increasing the chance of finding a more suitable habitat to restart a population (Komárek \& Anagnostidis 2005).

\section{Effects of salinity on total MC concentration}

Identification of MC profiles of the PMC1014.18 strain (performed by ESI-LC MS/MS) revealed that MC-LR is one of two major variants which is, with the dominance of Asp3 MC-RR, characteristic of P. agardhii (Fastner et al. 1999; Kurmayer et al. 2005). In our study, total MC concentration was positively correlated with biomass of $P$. agardhii in all but one salinity treatment $\left(15 \mathrm{~g} \mathrm{l}^{-1}\right)$, and corroborates previous studies (Dolman et al. 2012; Lyck 2004; Mazur-Marzec et al. 2008; Paerl \& Otten 2013). The relatively constant proportion of MC content from days 2 to 10 for the $15 \mathrm{~g} \mathrm{l}^{-1}$ treatment revealed no minute-lethal effects of the PMC1014.18 strain, suggesting a rather high tolerance of this strain to the salt stressor. Indeed, no drastic effects were recorded immediately, or within $24 \mathrm{~h}$, as reported for other cyanobacteria when exposed to a pulsed salt treatment (Tolar 2012) that released massive intracellular MCs linked to osmotic shock and cell death (Allakhverdiev \& Murata 2008).

In our study, MC quotas were not significantly different from 10 to $15 \mathrm{~g} \mathrm{l}^{-1}$, suggesting that cells coped with this stressor for a long period (from 2 to 18 days; Fig. 12). Some studies have shown that salinities up to $10 \mathrm{gl}^{-1}$ do not affect MC quota for Microcystis, 


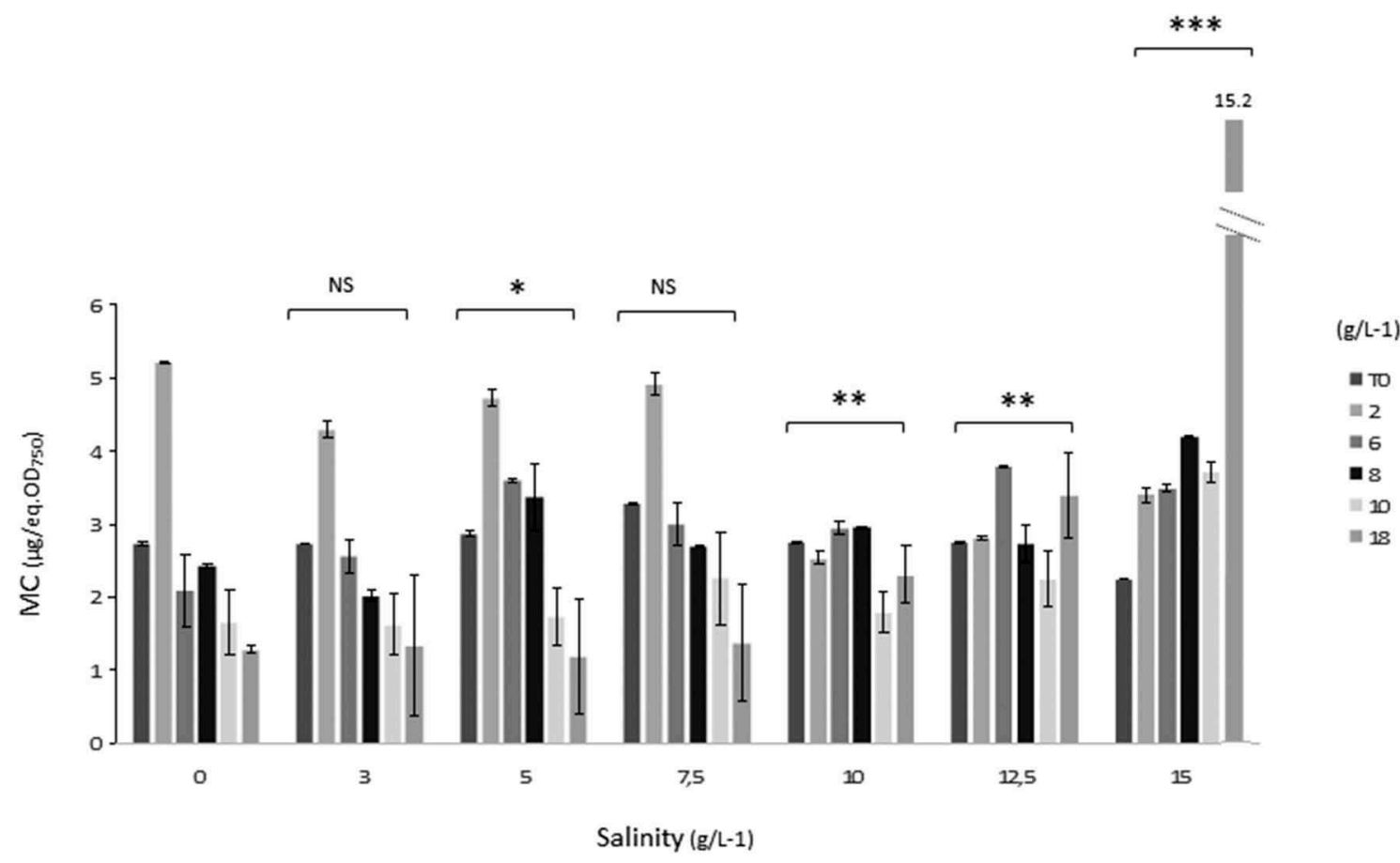

Fig. 12. Evolution of MC content (expressed as eq MC-LR $\mu \mathrm{g} /$ biomass) in the Planktothrix agardhi PMC1014.18, for each salinity treatment, from day 0 to day 18 ; asterisks indicate significant differences compared to control (Mann-Whitney U test). NS, Not significant; ${ }^{*}, P<0.05 ;{ }^{* *}, P<0.01 ;{ }^{* * *}, P<0.001$ ).

Anabaena or Anabaenopsis (Black et al. 2011; Martin-Luna et al. 2015). Surprisingly, at the end of the experiment for the $15 \mathrm{gl}^{-1}$ treatment, a maximal MC peak was detected, which was seven times higher than control, and five times higher than the previous $\mathrm{MC}$ amount at day 10 . Considering the decline in cell density and the increased number of short fragments, this suggests that massive cell disruption had occurred, releasing a large quantity of free MC (only free-MC fraction is detected by ELISA). Thus, MC may accumulate over several days with a stable MC fraction in the medium. Indeed, some $\mathrm{MC}$ variants can be detected and remain intact for several months (Miller et al. 2010; Zastepa et al. 2014), and may directly affect all organisms in the environment (Preece et al. 2017). Because ELISA was performed on both the extra- and intra-cellular MC fractions throughout the experiment, it is possible that the high level of $\mathrm{MC}$ production by living cells contributed to total MC concentration.

\section{Ecological implications and perspectives}

Salinity is an important abiotic factor that affects physiological and ecological performance of phytoplankton species, including cyanobacteria (De Pace et al. 2014; Teikaki et al. 2018; Tonk et al. 2007). We focused on the morphological and physiological changes of $P$. agardhii, a dominant species from a brackish pond that might therefore be pre-adapted to varying salinities (Vergalli 2013). Over the last decade, several episodes of increasing salinities ( 3 to $8 \mathrm{~g} \mathrm{l}^{-1}$ ) were recorded in this pond, which may have selected ecotypes adapted to the changing environment, as suggested by Kirkwood et al. (2008). Therefore, the highest salt concentration that we tested, i.e. $15 \mathrm{~g} \mathrm{l}^{-1}$, did not seem to be a threshold limit, at least after 20 days. Accordingly, the MC-producing strain PMC1014.18 can be proposed as a good candidate to further transcriptomic analyses to better understand its ability to adapt to increased salinity. Identification of salt-tolerant genotypes are still few in literature (Tanabe et al. 2018), and there are no reports for P. agardhii. Microcystis (another potential MC-producing cyanobacterium) strains that proliferate in brackish water have genes for synthesis of the osmolyte sucrose (Tanabe et al. 2018). Other reports suggest that low halotolerant strains can produce various compatible solutes such as trehalose and sucrose (Klähn \& Hagemann 2011) while estuarine cyanobacterial species, i.e. those acclimated to high salt concentrations near full seawater, have genes for sucrose synthesis with a suite of general and salt-stress-specific genes and regulatory systems enabling them to cope with changing environments (Tanabe et al. 2018; Teikaki et al. 2018, 2019). Earlier studies reported controversial results on cyanobacterial responses and capacity to cope with salt-stress (De Pace et al. 2014; Tolar 2012; Tonk et al. 2007), even at the intraspecific level (Otsuka et al. 1999). While some Microcystis strains resisted $10 \mathrm{~g} \mathrm{l}^{-1}$ of $\mathrm{NaCl}$ (Orr et al. 2004; Tonk et al. 2007), others reached their limit at $2 \mathrm{~g}^{-1}$, leading the authors to consider this as a strain-specific halotolerance rather than as a species-specific trait (Orr et al. 2004).

Genomic plasticity associated with ability to tolerate salt variations raises the question of persistence in downstream waters. These include coastal areas after meteorological-drifting events caused by strong rainfall or floods, and/or frequent water intrusion into estuarine ecosystems (De Pace et al. 2014; Nielsen et al. 2008). Indeed, the salinity gradients of sensitive ecosystems such as lagoons, wetlands, bays and estuaries are highly variable with significant changes in $\mathrm{NaCl}$ levels associated with tidal and seasonal cycles (Cloern \& Jassby 2012; Schumann et al. 2006). These salt fluctuations in the freshwater-estuarine-marine continuum are a driving force that could make aquatic species respond and 
adapt to salinity pressures. This could be a serious issue, as MCproducing cyanobacterial species such as $P$. agardhii (in this study), Microcystis aeruginosa (Teikaki et al. 2018) and Dolichospermum spp. (Teikaki et al. 2019) can survive and still maintain (and even increase) their toxin-producing ability under varying salinities. This will contribute to serious aquaculture and fishery farm contamination along the freshwater-marine continuum (Bergmann et al. 2008). Finally, as climate models predict warmer surface waters and higher evaporation in shallow water systems (Pearl \& Huisman 2008), it will be crucial to evaluate the impact of salinity oscillations on cyanobacterial expansion and MC production in a broader context, i.e. in other systems around the world.

Increasing salinity seems to prevent cyanobacterial bloom formation as elevated concentrations of $\mathrm{NaCl}$ (up to $12.5 \mathrm{~g}$ $\mathrm{I}^{-1}$ ) affect growth and morphology of P. agardhii PMC1014.18, including lower growth rates and an increase in the number of short broken filaments. However, examination of chlorophyll fluorescence within these shortened filaments demonstrate that the cells inside the fragments are still viable. This could be associated with a defence mechanism used by cells to preserve energy and survive unfavourable conditions. Indeed, P. agardhii can tolerate brackish water (from 1 to $9 \mathrm{~g} \mathrm{l}^{-1}$ ) and even higher levels of salinity, such as $15 \mathrm{~g} \mathrm{l}^{-1}$, without lethal salt-shock, at least for 18 days. This highlights a possible survival mechanism of cyanobacteria in brackish to coastal environments under climate change conditions, and raises the issue of their effect on human health, as we found a constant amount of free MC products over time in this investigation. Finally, there is a need to further investigate the effects of gradual and repetitive drought, rather than drastic salinity shocks, as an indirect effect of global warming changes on the acclimation and/or adaptive response of these filamentous toxic cyanobacteria.

\section{ACKNOWLEDGEMENTS}

Many thanks to staff of the mass spectrometry facilities of MNHN (Paris, France) and the technical coordinators from SIBOJAÏ.

\section{FUNDING}

J Vergalli was a recipient of a Ph.D fellowship from the French Department 'Provence Alpes Cote d'Azur', France.

\section{REFERENCES}

Allakhverdiev S.I. \& Murata N. 2008. Salt stress inhibits photosystems II and I in cyanobacteria. Photosynthesis Research 98: 529-539. DOI: 10.1007/s11120-008-9334-x.

Babica P., Bláha L. \& Maršálek B. 2006. Exploring the natural role of microcystins-a review of effects on photoautotrophic organisms. Journal of Phycology 42: 9-20. DOI: 10.1111/j.1529-8817.2006.00176.x.

Bergmann I., Geiss-Brunschweiger U., Hagemann M. \& Schoor A. 2008. Salinity tolerance of the chlorophyll b-synthesizing cyanobacterium Prochlorothrix hollandica strain SAG 10.89. Microbiolal Ecology 55: 685-696. DOI: 10.1007/s00248-007-9311-5.

Black K., Yilmaz M. \& Philips E.J. 2011. Growth and toxin production by Microcystis aeruginosa PCC 7806 (Kutz.) Lemmerman at elevated salt concentrations. Journal of Environmental Protection 2: 669-674. DOI: 10.4236/jep.2011.26077.
Briand J.F., Jacquet S., Flinois C., Avois-Jacquet C., Maisonnette C., Leberre B. \& Humbert J.F. 2005. Variations in the microcystin production of Planktothrix rubescens (Cyanobacteria) assessed from a four-year survey of Lac du Bourget (France) and from laboratory experiments. Microbial Ecology 50: 418-428. DOI: 10.1007/s00248-005-0186-Z.

Carey C.C., Ibelings B.W., Hoffmann E.P., Hamilton D.P. \& Brookes J.D. 2012. Eco-physiological adaptations that favour freshwater cyanobacteria in a changing climate. Water Research 46: 1394-1407. DOI: 10.1016/j.watres.2011.12.016.

Castenholtz R.W. \& Waterbury J.B. 1989. Group I. Cyanobacteria. In: Bergey's manual of systematic bacteriology, Vol. 3 (Ed. by J.T. Stanley, M.P. Bryant, N. Pfenning \& J.G. Holt), pp. 473-599. Williams \& Wilkins, Baltimore, Maryland, USA.

Chomerat N., Garnier R., Bertrand C. \& Cazaubon A. 2007. Seasonal succession of cyanoprokaryotes in a hypereutrophic oligo-mesohaline lagoon from the South of France. Estuarine Coastal and Shelf Science 72: 591-602. DOI: 10.1016/j.ecss.2006.11.008.

Chorus I. \& Bartram J. 1999. Toxic cyanobacteria in water: a guide to their public health consequences, monitoring and management. CRC Press, Taylor \& Francis Group, London, UK, 698 pp.

Cloern J.E. \& Jassby A.D. 2012. Drivers of change in estuarine-coastal ecosystems: discoveries from four decades of study in San Francisco Bay. Reviews of Geophysics 50: 77-81.

Combes A., Dellinger M., Cadel-six S., Amand S. \& Comte K. 2013. Ciliate Nassula sp. grazing on a microcystin-producing cyanobacterium (Planktothrix agardhii): impact on cell growth and in the microcystin fractions. Aquatic Toxicology 126: 435-441. DOI: 10.1016/j. aquatox.2012.08.018.

Corrobé L.M., Obiol A., Solé A. \& Esteve I. 2017. A novel method to analyse in vivo the physiological state and cell viability of phototrophic microorgansims by confocal scanning microscopy using a dual laser. Journal of Microsopy: 268. DOI:10.1111/jmi.12586.

Davis T., Berry W.D.L., Boyer G.L. \& Gobler C.J. 2009. The effects of temperature and nutrients on the growth and dynamics of toxic and non-toxic strains of Microcystis during cyanobacteria blooms. Harmful Algae 8: 715-725. DOI: 10.1016/j.hal.2009.02.004.

De Pace R., Vita V., Bucci M.S., Gallo P. \& Bruno M. 2014. Microcystin concentration in sea mussel farms from the Italian southern Adriatic coast following cyanobacterial blooms in the artificial reservoir. Journal of Ecosystems 1: 1-12. DOI: 10.1155/2014/374027.

Djediat C., Moyenga D., Malécot M., Comte K., Yéprémian C., Bernard C., Puiseux-Dao S. \& Edery M. 2011. Oral toxicity of the microcystin-containing cyanobacterium Planktothrix agardhii to the medaka fish (Oryzias latipes). Toxicon 58: 112-122. DOI: 10.1016/j. toxicon.2011.05.011.

Dolman A.M., Rücker J., Pick F.R., Fastner J., Rohrlack T., Mischke U. \& Wiedner C. 2012. Cyanobacteria and cyanotoxins: the influence of nitrogen versus phosphorus. PLoS ONE: 7. DOI:10.1371/journal. pone.0038757.

Downing T.G., Sember C.S., Gehringer M.M. \& Leukes V. 2005. Medium $\mathrm{N}: \mathrm{P}$ ratios and specific growth rate comodulate microcystin and protein content in Microcystis aeruginosa PCC7806 and Microcystis aeruginosa UV027. Microbial Ecology 49: 468-473. DOI: 10.1007/ s00248-004-0054-2.

Fastner J., Erhard M., Carmichael W.W., Sun F., Rinehart K.L., Ronicke H. \& Chorus I. 1999. Characterization and diversity of microcystins in natural blooms and strains of the genera Microcystis and Planktothrix from German freshwaters. Archiv Fur Hydrobiologie 145: 147-163. DOI:10.1127/archiv-hydrobiol/145/1999/147.

Ferjani A., Mustardy L., Sulpice R., Marin K., Suzuki I., Hagemann M. \& Murata N. 2003. Glucosylglycerol, a compatible solute, sustains cell division under salt stress. Plant Physiology 131: 1628-1637. DOI: 10.1104/pp.102.017277.

Hagemann M. 2011. Molecular biology of cyanobacterial salt acclimation. FEMS Microbiology Reviews 35: 87-123. DOI: 10.1111/ j.1574-6976.2010.00234.x.

Hesse K. \& Kohl J.G. 2001. Effects of light and nutrient supply on growth and microcystin content of different strains of Microcystis aeruginosa. In: Cyanotoxins - occurrence, causes, consequences (Ed. by I. Chorus), pp. 104-114. Springer, Berlin, Germany. 
Kaebernick M. \& Neilan B.A. 2001. Ecological and molecular investigations of cyanotoxin production. FEMS Microbiology Ecology 35: 1-9. DOI: 10.1016/S0168-6496(00)00093-3.

Kahm M., Hasenbrink G., Lichtenberg-Frate H., Ludwig J. \& Kschischo M. 2010. Grofit: fitting biological growth curves with R. Journal of Statistical Software 33: 1-21. DOI:10.18637/jss.v033.i07.

Kirkwood A.E., Buchheim J.A., Buchheim M.A. \& Henley W.J. 2008. Cyanobacterial diversity and halotolerance in a variable hypersaline environment. Microbial Ecology 55: 453-465. DOI: 10.1007/s00248007-9291-5.

Klähn S. \& Hagemann M. 2011. Compatible solute biosynthesis in cyanobacteria. Environmental Microbiology 13: 551-562. DOI:10.1111/ j.1462-2920.2010.02366.x.

Komárek J. \& Anagnostidis K. 2005. Cyanoprokaryota 2. Teil: oscillatoriales. Elsevier GmbH, München. Springer Spektum, Munich, Germany, 759 pp.

Kotai J. 1972. Instructions for preparation of modified nutrient solution Z8 for algae, Norwegian Institute for Water Research. Publication B11/69, Oslo, Blindern, 5 pp.

Kurmayer R., Christiansen G., Fastner J. \& Borner T. 2004. Abundance of active and inactive microcystin genotypes in populations of the toxic cyanobacterium Planktothrix spp. Environmental Microbiology 6: 831-841. DOI: 10.1111/j.1462-2920.2004.00626.x.

Kurmayer R., Christiansen G., Gumpenberger M. \& Fastner J. 2005. Genetic identification of microcystin ecotypes in toxic cyanobacteria of the genus Planktothrix. Microbiology-SGM 151: 1525-1533. DOI: 10.1099/mic.0.27779-0.

Leao P.N., Vasconcelos M. \& Vasconcelos V.M. 2009. Allelopathy in freshwater cyanobacteria. European Journal of Phycology 35: 271-282. DOI: 10.1080/09670260802652156.

Lehman P.W., Boyer G., Hall C., Waller S. \& Gehrts K. 2005. Distribution and toxicity of a new colonial Microscystis aeruginosa bloom in the San Francisco Bay Estuary, California. Hydrobiologia 541: 87-89. DOI: 10.1007/s10750-004-4670-0.

Lyck S. 2004. Simultaneous changes in cell quotas of microcystin, chlorophyll $a$, protein and carbohydrate during different growth phases of a batch culture experiment with Microcystis aeruginosa. Journal of Plankton Research 26: 727-736. DOI: 10.1093/plankt/fbh071.

Martin-Luna B., Sevilla E., Bes M.T., Fillat M.F. \& Peleato M.L. 2015. Variation in the synthesis of microcystin in response to osmotic stress in Microcystin aeruginosa PCC 7806. Limnetica 34: 205-2014.

Mazur-Marzec H., Spoof L., Kobos J., Plinski M. \& Meriluoto J. 2008. Cyanobacterial hepatotoxins, microcystins and nodularins, in fresh and brackish waters of the Pomeranian Province, northern Poland Oceanological and Hydrobiological Studies 37: 3-21. DOI: 10.2478/ v10009-008-0014-0.

Miller M.A., Kudela R.M., Mekebri A., Crane D., Oates S.C., Tinker M. T., Staedler W., Miller M., Toy-Choutka W.A., Dominik S. et al. 2010. Evidence for a novel marine harmful algal bloom cyanotoxin (microcystin) transfer from land to sea otters. PLOS ONE 5: 1-11. DOI: 10.1371/journal.pone.0012576.

Montgomery B.L. 2015. Light-dependent governance of cell shape dimensions in cyanobacteria. Frontiers in Microbiology 6: 514. DOI: 10.3389/fmicb.2015.00514.

N’Dong M., Bird D., Tri N.Q., De Boutray M.L., Zamyadi A., VinconLeite B., Lemaire B.J., Prevost M. \& Dorner S. 2014. Estimating the risk of cyanobacterial occurrence using an index integrating meteorological factors: application to drinking water production. Water Research 56: 98-108. DOI: 10.1016/j.watres.2014.02.023

Nielsen D.L., Brock M.A., Vogel M. \& Petrie R. 2008. From fresh to saline: a comparison of zooplankton and plant communities developing under a gradient of salinity with communities developing under constant salinity levels. Marine and Freshwater Research 59: 549-559. DOI: $10.1071 /$ MF07166.

Orr P.T., Jones G.J. \& Douglas G.B. 2004. Response of cultured Microcystis aeruginosa from the Swan River, Australia, to elevated salt concentration and consequences for bloom and toxin management in estuaries. Marine and Freshwater Research 55: 277-283. DOI: 10.1071/MF03164.
Otsuka S., Suda S., Li R., Watanabe M., Oyaizu H., Matsumoto S., Watanabe S. \& Makoto M. 1999. Phylogenetic relationships between toxic and non-toxic strains of the genus Microcystis based on 16S to 23S internal transcribed spacer sequence. FEMS Microbiology Letters 172: 15-21. DOI: $10.1111 / j .1574 .6968$.

Paerl H.W. \& Otten T. 2013. Harmful cyanobacterial blooms: causes, consequences, and controls. Microbial Ecology 65: 995-1010. DOI: 10.1007/s00248-012-0159-y.

Paerl H.W. \& Paul V.J. 2012. Climate change: links to global expansion of harmful cyanobacteria. Water Research 46: 1349-1363. DOI: 10.1016/j.watres.2011.08.002.

Pearl H.W. \& Huisman J. 2008. Blooms like it hot. Science 320: 57-58. DOI: $10.1126 /$ science. 1155398 .

Pearson L., Mihali T., Moffitt M., Kellmann R. \& Neilan B. 2010. On the chemistry, toxicology and genetics of the cyanobacterial toxins, microcystin, nodularin, saxitoxin and cylindrospermopsin. Marine Drugs 8: 1650-1680. DOI: 10.3390/md8051650.

Poulíčková A., Hašler P. \& Kitner M. 2004. Annual cycle of Planktothrix agardhii. nature population. International Review of Hydrobiology 89: 278-288. DOI: 10.1002/iroh.200310716.

Pouneva I. 1997. Evaluation of algal culture viability and physiological state by fluorescent microscopic methods. Bulgarian Journal of Plant Physiology 23: 67-76.

Pouria S., De Andrade A., Barbosa J., Cavalcanti R.L., Barreto V.T.S., Ward C.J., Preiser W., Poon G.K., Neild G.H. \& Codd G.A. 1998. Fatal microcystin intoxication in haemodialysis unit in Caruaru, Brazil. Lancet 352: 21-26. DOI: 10.1016/S0140-6736(97)12285-1.

Preece E., Hardy F.J., Moore B.C. \& Bryan M. 2017. A review of microcystin detections in estuarine and marine waters: environmental implications and human health risks. Harmful Algae 61: 31-45. DOI: 10.1016/j.hal.2016.11.006.

Reguero B.G., Losada I.J., Diaz-Simal P., Mendez F.J. \& Beck M.W. 2015. Effects of climate change on exposure to coastal flooding in Latin America and the Caribbean. PLOS ONE 10: e0133409. DOI: 10.1371/ journal.pone.0133409.

Ressom R., San Soong F., Fitzgerald J. \& Turczynowicz L. 1994. Health effects of toxic Cyanobacteria (blue-green algae), Vol. 1. National Health and Medical Council. The Australian Government Publishing Services, Camberra, Australia. 108 pp.

Rippka R. 1988. Isolation and purification of Cyanobacteria. Methods in Enzymology 167: 3-27. DOI:10.1016/0076-6879(88)67004-2.

Robson B.J. \& Hamilton D.P. 2003. Summer flow event induces a cyanobacterial bloom in a seasonal western Australia estuary. Marine and Freshwater Research 54: 139-151. DOI: 10.1071/ MF02090.

Rojo C. \& Alvarez Cobelas M. 1994. Population dynamics of Limnothrix redekei, Oscillatoria lanceaeformis, Planktothrix agardhii and Pseudanabaena limnetica (cyanobacteria) in a shallow hypertrophic lake (Spain). Hydrobiologia 275: 165-171. DOI: 10.1007/BF00026708.

Romo S. \& Miracle M.R. 1993. Long-term periodicity of Planktothrix agardhii, Pseudanabaena galeata and Geitlerinema sp. in a shallow hypertrophic lagoon, the Albufera of Valencia (Spain). Archiv of Hydrobiologie 126: 469-486.

Roth J., Haycock K., Gagno J., Soper C. \& Caldarola J. 1995. L'intégré des analyses de données. Statview Software, Ed., Abacus Concepts, California, USA. 302 pp.

Schumann R., Baudier H., Glass A., Dumcke K. \& Karsten U. 2006. Long-term observations on salinity dynamics in a tideless shallow coastal lagoon on the southern Baltic Sea coast and their biological relevance. Journal of Marine Systems 60: 330-344. DOI:10.1016/j. jmarsys.2006.02.007.

Sevilla E., Martin-Luna B., Vela L., Bes M.T., Fillat M.F. \& Peleato M.L. 2008. Iron availability affects $m c y D$ expression and microcystin-LR synthesis in Microcystis aeruginosa PCC7806. Environmental Microbiology 10: 2476-2483. DOI: 10.1111/j.1462-2920.2008.01663.x.

Shimizu K., Sano T., Kubota R., Kobayashi N., Tahara M., Obama T., Sugimoto N., Nishimura T. \& Ikarashi Y. 2014. Effects of the amino acid constituents of microcystin variants on cytotoxicity to primary cultured rat hepatocytes. Toxins 6: 168-179. DOI: 10.3390/toxins6010168. 
Singh S.P. \& Montgomery B.L. 2013a. Distinct salt-dependent effects impair Fremyella diplosiphon pigmentation and cellular shape. Plant Signal Behavior 8: 146-172. DOI: 10.4161/psb.24713.

Singh S.P. \& Montgomery B.L. 2013b. Salinity impacts photosynthetic pigmentation and cellular morphology changes by distinct mechanisms in Fremyella diplosiphon. Biochemical and Biophysical Research Communications 433: 84-89. DOI: 10.1016/j.bbrc.2013.02.060.

Sivonen K. \& Jones G. 1999. Toxic cyanobacteria in water. In: A guide to their public health consequences, monitoring and management, Vol. 1 (Ed. by I. Chorus \& J. Bartram), pp. 41-111. St Edmundsbury Press, Suffolk, UK

Song L., Sano T., Li R., Watanabe M.M., Liu Y. \& Kaya K. 1998. Microcystin production of Microcystis viridis (Cyanobacteria) under different culture conditions. Phycological Research 46: 19-23. DOI: 10.1046/j.1440-1835.1998.00120.x

Spoof L. \& Catherine A. 2017. Appendix 3: tables of microcystins and nodularins, in handbook of cyanobacterial monitoring and cyanotoxin analysis. John Wiley \& Sons, Ltd., Chichester, UK. 526-537 pp.

Sun J. \& Liu D.Y. 2003. Geometric models for calculating cell biovolume and surface area for phytoplankton. Journal of Plankton Research 25: 1331-1346. DOI: 10.1093/plankt/fbg096.

Tanabe Y., Hodoki Y., Sano T., Tada K. \& Watanabe M.M. 2018. Adaptation of the freshwater bloom-forming cyanobacterium Microcystis aeruginosa to brackish water is driven by recent horizontal transfer of sucrose genes. Frontiers in Microbiology 9: 1-11. DOI: 10.3389/fmicb.2018.01150.

Teikaki J.E., Hou S., Wahlsten M., Hess W. \& Sivonen K. 2018. Comparative genomics of the Baltic Sea toxic cyanobacteria Nodularia spumigena UHCC 0039 and its response to varying salinity. Frontiers in Microbiology 9: 356. DOI: 10.3389/ fmicb.2018.00356.

Teikaki J.E., Popin R.V., Wahlsten M., Hess W.R. \& Sivonen K. 2019. Insight into the genome and brackish water adaptation strategies of toxic and bloom-forming Baltic sea Dolichospermum sp. UHCC 0315. Scientific Reports 9: 4888. DOI: 10.1038/s41598-019-40883-1.

Tolar S. 2012. Salinity tolerance in cyanobacteria and its implications for expansion into estuaries. Undergraduate Honors Thesis, University of North Carolina at Chapel Hill, North Carolina, USA.
Tonk L., Bosch K., Visser P.M. \& Huisman J. 2007. Salt tolerance of the harmful cyanobacterium Microcystis aeruginosa. Aquatic Microbial Ecology 46: 117-123. DOI: 10.3354/ame046117.

Tonk L., Visser P.M., Christiansen G., Dittmann E., Snelder E., Wiedner C., Mur L.R. \& Huisman J. 2005. The microcystin composition of the cyanobacterium Planktothrix agardhii changes toward a more toxic variant with increasing light intensity. Applied and Environmental Microbiology 71: 5177-5181. DOI: 10.1128/AEM.71.9.5177-5181.2005.

Twoney L.J., Piehler M.F. \& Paerl H.W. 2002. Priority parameters for monitoring of freshwater and marine systems and their measurement. In: Environmental monitoring, Vol. 2 (Ed. by H.I. Inyang \& D. Daniels), pp. 318-339. EOLSS Publishers, Oxford, UK.

Vergalli J. 2013. Versatilité écologique de la cyanobactérie potentiellement toxique Planktothrix agardhii: Influence de la salinité? PhD thesis, Université Aix-Marseille III, France. 255 pp.

Villena M.J. \& Romo S. 2003. Phytoplankton changes in a shallow Mediterranean lake (Albufera of Valencia, Spain) after sewage diversion. Hydrobiologia 506: 281-287. DOI: 10.1023/B: HYDR.0000008565.23626.aa.

Wiedner C., Visser P.M., Fastner J., Metcalf J.S., Codd G.A. \& Mur L.R. 2003. Effects of light on the microcystin content of microcystis strain PCC 7806. Applied and Environmental Microbiology 69: 1475-1481. DOI: 10.1128/AEM.69.3.1475-1481.2003.

Yuan M., Namikoshi M., Otsuki A., Watanabe F. \& Rinehart K.L. 1999. Electrospray ionization mass spectrometric analysis of microcystins, cyclic heptapeptide hepatotoxins: modulation of charge states and $[\mathrm{M}$ $+\mathrm{H}]+$ to $[\mathrm{M}+\mathrm{Na}]+$ ratio. Journal of the American Society for the Mass Spectrometry 10: 1138-1151. DOI: 10.1016/S1044-0305(99) 00088-4.

Zastepa A., Pick F.R. \& Blais J.M. 2014. Fate and persistence of particulate and dissolved microcystin-LA from microcystis blooms. Human and Ecological Risk Assessment 20: 1670-1686. DOI: 10.1080/ 10807039.2013.854138.

Zilliges Y., Kehr J.C., Meissner S., Ishida K., Mikkat S. \& Hagemann M. 2011. The cyanobacterial hepatotoxin microcystin binds to proteins and increases the fitness of Microcystis under oxidative stress conditions. PLoS ONE 6: e17615. DOI: 10.1371/journal.pone.0017615. 